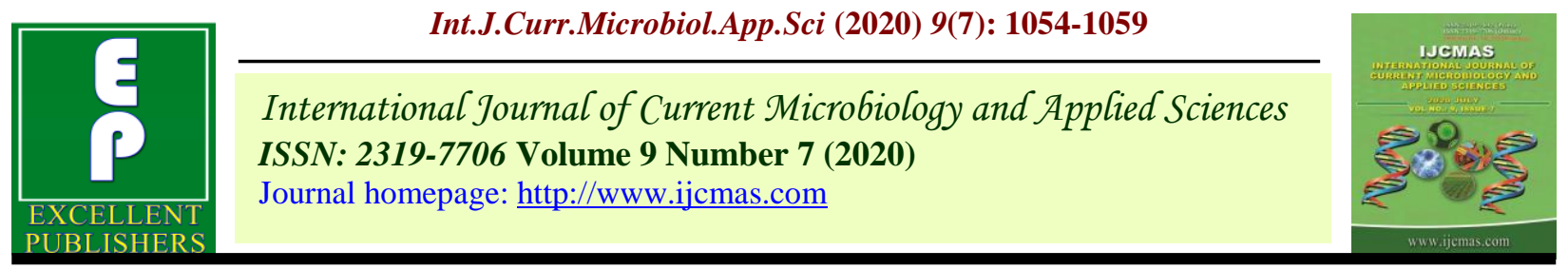

Original Research Article

https://doi.org/10.20546/ijcmas.2020.907.123

\title{
Effect of Integrated Nutrient Management on Productivity of Groundnut (Arachis hypogaea L.) and Soil Physical Properties in Bastar Plateau
}

\author{
Mukesh Kumar*, T. Chandrakar, Dileshwar Prashad Sahu, \\ Karuna Kant Joshi and Poornima Sahu
}

Department of Soil Science and Agricultural Chemistry, Indira Gandhi Agricultural

University, Raipur (C.G), INDIA

*Corresponding author

\begin{tabular}{l} 
K e y w o r d s \\
Integrated nutrient \\
management, \\
Organic manure, \\
Yield attributes, Oil \\
content, Groundnut, \\
Growth \\
\hline Article Info \\
Accepted: \\
11 June 2020 \\
Available Online: \\
10 July 2020
\end{tabular}

\section{A B S T R A C T}

A field experiment was conducted during kharif, Season of 2016 to study the effect of integrated nutrient management in groundnut at Upland field under AICRP-Dry land Agriculture, S.G. College of Agriculture and Research Station, Kumrawand, Jagdalpur, Bastar (C.G.). The experiment comprised 10 treatment combinations $\quad \mathrm{T}_{1}$-control, $\mathrm{T}_{2}$-GRD $\quad(30: 60: 30:: \mathrm{NPK} \quad \mathrm{kg} / \mathrm{ha}), \quad \mathrm{T}_{3^{-}}$ GRD+ZnSO $@$ @25kg/ha, T 4 GRD + FYM@5t/ ha in furrow, T 5 -GRD+FYM@5t/ha in furrow + $\mathrm{ZnSO}_{4} @ 25 \mathrm{~kg} / \mathrm{ha}, \mathrm{T}_{6}-50 \% \mathrm{GRD}+\mathrm{FYM} @ 5 \mathrm{t} / \mathrm{ha}$ in furrow, $\mathrm{T}_{7}-50 \%$ GRD + ZnSO $@$ @25kg/ha +FYM @ 5t/ha in furrow, T 8 - $100 \%$ GRD +Lime @3q/ ha $+\mathrm{FYM} @ 5 \mathrm{t} / \mathrm{ha}$ in furrow, $\mathrm{T}_{9}-100 \% \mathrm{GRD}+\mathrm{MgSO}_{4} @ 15 \mathrm{~kg} / \mathrm{ha}+\mathrm{FYM} @ 5 \mathrm{t} / \mathrm{ha}$ in furrow and $\mathrm{T}_{10^{-}}$100\% GRD + lime@3q/ha+ $\mathrm{MgSO}_{4} @ 15 \mathrm{~kg} / \mathrm{ha}+\mathrm{FYM} 5 \mathrm{t} / \mathrm{ha}$ in furrow. The maximum pod yield $\left(20.52 \mathrm{qha}^{-1}\right)$ was recorded under treatment 100\%GRD+ lime@3q/ha+MgSO $@$ @ 15kg /ha+FYM5t/ha in furrow $\left(\mathrm{T}_{10}\right)$, The maximum haulm yield $\left(33.07 \mathrm{q} / \mathrm{ha}^{-1}\right)$ was recorded under 100\%GRD+ Lime@3q/ ha+FYM 5t/ha in furrow $\left(\mathrm{T}_{8}\right)$ andThe maximum harvest index $(38.8 \%)$ was recorded under 100\%GRD+FYM@5t/ ha in furrow $\left(\mathrm{T}_{4}\right)$.Different fertility treatments had significant effect on growth, yield attributes, yield and oil content in groundnut.

\section{Introduction}

Groundnut (Arachis hypogaea L.) is one of the major oilseed crop in India. Althought India ranks 1 st in the world in respect of area and production, however, ranks 8th in productivity (Sonawane et al., 2010). It is a valuable cash crop planted by millions of small farmers because of its economic and nutritional value. Groundnut which helps to enrich the soil nitrogen and ultimately maintain soil health. Its kernels are rich source of edible oil and protein. It contains on an average $45-50 \%$ oil, $25-30 \%$ protein, $20 \%$ carbohydrate, $5 \%$ fiber and ash and is a rich source of $\mathrm{Ca}, \mathrm{Fe}$, vitamins $\mathrm{A}, \mathrm{B}, \mathrm{E}$, and $\mathrm{K}$, which make a substantial contribution to human nutrition. About two third of world 
production is crushed for oil and remaining one third is consumed as food. Oilseed and are the second largest agri-commodity after cereals and value about $5 \%$ of gross national product and nearly $10 \%$ value of all agricultural products put together.. Groundnut is essentially a tropical crop. It requires a long and warm growing season. The most favorable climatic conditions for groundnut are a well distributed rainfall of at least $50 \mathrm{~cm}$. during growing season, abundance of sunshine and relatively warm temperatures $\left(25-28^{\circ} \mathrm{C}\right)$. Lower temperatures are not suitable for its proper development. During ripening period it requires about a month of warm and dry weather. Groundnut thrives best in well-drained sandy and sandy loam soils, as light soil helps in easy penetration of pegs and their development and also harvesting. Clay or heavy soils are not suitable for this crop, as they interfere in penetration of pegs and make harvesting difficult. Groundnut gives good yields in the soil with $\mathrm{pH}$ between 6.0-6.5. Groundnut is a unique and important oilseed crop of India. In India, groundnut is cultivated in $5.48 \mathrm{~m}$ ha with a production of $5.43 \mathrm{~m} \mathrm{t}$ and productivity of $991 \mathrm{~kg}$ ha-1 (2009-10). Groundnut is grown on nearly 23.95 million ha worldwide with the total production of 36.45 million tons and an average yield of $1520 \mathrm{~kg} / \mathrm{ha}$ in 2009 (FAOSTAT 2011).

\section{Materials and Methods}

A field experiment was conducted during kharif season of 2016 at Upland field under AICRP-Dry land Agriculture, S.G. College of Agriculture and Research Station, Kumrawand, Jagdalpur, Bastar (C.G.) The soil of the experimental site was sandy loam (52\% sand, 26\% silt and $22 \%$ clay), slightly acidic in reaction ( $\mathrm{pH} 4.8)$, midium in organic carbon (0.61\%), available nitrogen (205 $\mathrm{kg} / \mathrm{ha})$, available phosphorus (12.3 kg/ha), medium in available potassium $(198 \mathrm{~kg} / \mathrm{ha})$, available sulphur (9.5kg/ha),available calcium(92 kg/ha), available $\mathrm{Mg}$ (96 $\mathrm{kg} / \mathrm{ha}$ )and (zinc 1.2ppm) respectively. The experiment comprised 10 treatment combinations. $\mathrm{T}_{1}$-control, $\mathrm{T}_{2}$-GRD (30:60:30:: NPK kg/ha), $\mathrm{T}_{3}-\mathrm{GRD}+\mathrm{ZnSO}_{4} @ 25 \mathrm{~kg} / \mathrm{ha}$, $\mathrm{T}_{4} \mathrm{GRD}+\mathrm{FYM} @ 5 \mathrm{t} /$ ha in furrow, $\mathrm{T}_{5^{-}}$ GRD+FYM@5t/ha in furrow + $\mathrm{ZnSO}_{4} @$ $25 \mathrm{~kg} / \mathrm{ha}, \mathrm{T}_{6}-50 \% \mathrm{GRD}+\mathrm{FYM} @ 5 \mathrm{t} / \mathrm{ha}$ in furrow, $\mathrm{T}_{7}-50 \%$ GRD $+\mathrm{ZnSO}_{4} @ 25 \mathrm{~kg} / \mathrm{ha}$ $+\mathrm{FYM} @ 5 \mathrm{t} / \mathrm{ha}$ in furrow, $\mathrm{T}_{8}-100 \% \mathrm{GRD}$ +Lime@3q/ ha +FYM @ 5t/ha in furrow, T $^{-}$ 100\%GRD+ $\mathrm{MgSO}_{4} @ 15 \mathrm{~kg} / \mathrm{ha}+\mathrm{FYM}$ $@ 5 \mathrm{t} / \mathrm{ha}$ in furrow and $\mathrm{T}_{10^{-}} 100 \%$ GRD + lime@3q/ha+ MgSO $@$ @15kg/ha+ FYM 5t/ha in furrow.

These treatments were laid out in randomized block design with four replications, using seed rate $100 \mathrm{~kg} / \mathrm{ha}$ and sown on June 21, 2016and harvested on Oct. 18, 2016. The FYM was applied 25 days before crop sowing. The calculated quantity of chemical fertilizers as per treatment was applied at the time of bed preparation in respective treatment. Urea DAP and MOP were used as source of nitrogen, phosphorus, and potassium respectively.

Oil was extracted from seeds of groundnut of each plots with the help of Socs plus solvent extractor using hexane as solvent. The percent of oil present in a sample was calculated with the help of following formula:

Oil content $(\%)=\frac{\mathrm{W}_{2}-\mathrm{W}_{1}}{\mathrm{~W}}$

Where,

$\mathrm{W} 1$ = Initial weight of beaker

W2 $=$ Final weight of beaker $($ beaker + oil $)$

$\mathrm{W}=$ Weight of powdered sample $(2 \mathrm{~g})$ 


\section{Results and Discussion}

\section{Yield attributes and oil content}

\section{Yield attributes}

The effects of different levels of fertilizers and manures on a significant effect on number of pod/plant. The maximum values of these parameter(17.80 pods plant $\left.{ }^{-1}\right)$ were observed under 50\%GRD+ZnSO $\mathrm{Z}_{4} @ 25 \mathrm{~kg} / \mathrm{ha}+\mathrm{FYM}$ @5t/ha in furrow $\left(\mathrm{T}_{7}\right)$ (Table 1).In groundnut, application of fertilizers alone or in combinations with FYM increased the pod numbers as compared to control. (Singaravel et al., 2006) and (Gunri et al., 2012).The research findings indicate thata suitable combination of organic and inorganic fertilizers maintain a long term soil fertility and sustain high level of productivity (Pillai et al., 1985).

Application of different levels of fertilizer and manures significantly increased the yield attributes such as number of pods/plant, and 100 grain weight. The significantly highest values were obtained under $50 \% \mathrm{GRD}+\mathrm{ZnSO}_{4}$ @ 25kg/ha+ FYM @5t/ha in furrow ( $\mathrm{T}_{7}$ )and100\%GRD+lime@3q/ha+MgSO ${ }_{4} @ 15$ $\mathrm{kg} / \mathrm{ha}+\mathrm{FYM} \mathrm{5t/ha}$ in furrow $\left(\mathrm{T}_{10}\right)$ (Table 1). The same trend was also observed in pod, haulm, and biological yield. The maximum pod yield (20.52qha $\left.{ }^{-1}\right)$ was recorded under treatment 100\% GRD+ lime@ 3q/ha+ $\mathrm{MgSO}_{4} @ 15 \mathrm{~kg} / \mathrm{ha}+\mathrm{FYM} 5 \mathrm{t} / \mathrm{ha}$ in furrow $\left(\mathrm{T}_{10}\right)$. The maximum haulm yield $\left(33.07 \mathrm{q} / \mathrm{ha}^{-}\right.$ ${ }^{1}$ ) was recorded under 100\%GRD+ Lime@3q/ ha+FYM 5t/ha in furrow $\left(\mathrm{T}_{8}\right)$ andThe maximum harvest index $(38.8 \%)$ was recorded under 100\%GRD+FYM@5t/ ha in furrow $\left(\mathrm{T}_{4}\right)$.This might be attributed to the favourable effect of FYM on plant growth and consequently on yield attributes. Further, FYM increased the efficiency of humification. Humic acid in FYM enhanced theavailability of both native and added macro and micronutrients in soil and thus stimulated plant growth and improved yield attributes and yield significantly. The pod, haulm and biological yields of groundnut significantly increased with application of FYM along with fertilizers. Similar results were reported by Thorve et al., (2008) and Abraham et al., (2010) and Singh et al., (2011).

It may be due to application of inorganic $\mathrm{N}$ fertilizer with organic sources is known to reduce the $\mathrm{C}: \mathrm{N}$ ratio and stimulate the mineralization of organic $\mathrm{N}$ that in turn resulted in higher yields. Similar results were reported by Badole et al., (2004) and Laxminarayana et al., (2005).

\section{Oil content}

Oil content in groundnut increased significantly due to application of different level of fertilizers and manures. The maximum oil content $(49.18 \%)$ was recorded under 100\%GRD + $\mathrm{MgSO}_{4} @ 15$ kg/ha+ FYM $5 \mathrm{t} /$ ha in furrow $\left(\mathrm{T}_{9}\right)$ and the lowest oil content in control plot $\left(\mathrm{T}_{1}\right)(36.3 \%)$ (Table 1$)$. As, oil bio synthesis is a complex process it is always difficult to modulate its content in plant through Management practices. Similar results were reported by Kachot et al., (2001), Panwar et al., (2007) and Basu et al., (2008). Probable reason for increase in protein is that the nitrogen is an integral part of protein and phosphorus is an integral part of certain coenzyme involved in protein synthesis. The increase in protein synthesis in groundnut is mainly due to cumulative effect of pod yield. Similar results were also noted by Zalate et al., (2010)

\section{Physico-chemical properties of soil}

For the assessment of various physicochemical properties of the experiment site, surface soil sample $(0-15 \mathrm{~cm})$ were collected 
randomly with the help of auger and a respective composite sample was prepared. The soil was analyzed for its initial characteristics as per the methods mentioned below and some important physico-chemical properties of the soil are given in (Table 2)The soil of the experimental site was sandy loam (52\% sand, $26 \%$ silt and $22 \%$ clay), slightly acidic in reaction ( $\mathrm{pH} 4.8)$, midium in organic carbon $(0.61 \%)$, available nitrogen (205 kg/ha), available phosphorus (12.3 $\mathrm{kg} / \mathrm{ha})$, medium in available potassium (198 $\mathrm{kg} / \mathrm{ha})$, available sulphur ( $9.5 \mathrm{~kg} / \mathrm{ha})$, available calcium(92 $\mathrm{kg} / \mathrm{ha})$,available $\quad \mathrm{Mg} \quad(96$ $\mathrm{kg} / \mathrm{ha}$ )and (zinc 1.2ppm) respectively.

Table.1 Effect of treatments on yield and yield attributing characters of groundnut crop

\begin{tabular}{|c|c|c|c|c|c|c|}
\hline Treatment & $\begin{array}{l}\text { Pod / } \\
\text { plant }\end{array}$ & $\begin{array}{l}100 \text { grain } \\
\text { weight }\end{array}$ & $\begin{array}{l}\text { Pod yield } \\
\text { (Kg/ha) }\end{array}$ & $\begin{array}{l}\text { Haulm } \\
\text { yield } \\
\text { (kg/ha) }\end{array}$ & $\begin{array}{l}\text { Harvest } \\
\text { index } \\
(\%)\end{array}$ & $\begin{array}{l}\text { Oil } \\
\text { content } \\
(\%)\end{array}$ \\
\hline Control & 13.30 & 30.31 & 1013 & 1774.00 & 36.3 & 45.65 \\
\hline $\begin{array}{l}\text { GRD (30:60:30:: NPK } \\
\text { Kg/ha) }\end{array}$ & 15.60 & 31.92 & 1729.75 & 2798.00 & 38.2 & 47.28 \\
\hline GRD+ZnSO ${ }_{4} @ 25$ kg & 17.30 & 30.71 & 1877 & 3057.50 & 38.0 & 47.75 \\
\hline $\begin{array}{l}\text { GRD +FYM@5t/ ha in } \\
\text { furrow }\end{array}$ & 14.55 & 32.14 & 1890.5 & 2987.50 & 38.8 & 47.83 \\
\hline $\begin{array}{l}\text { GRD+FYM@5t/ha in } \\
\text { furrow+ZnSO } @ 25 \mathrm{~kg}\end{array}$ & 16.50 & 32.88 & 1879.75 & 3034.00 & 38.3 & 48.23 \\
\hline $\begin{array}{l}50 \% \text { GRD +FYM @ 5t/ha in } \\
\text { furrow }\end{array}$ & 13.20 & 32.60 & 1748.5 & 2965.50 & 37.1 & 48.13 \\
\hline $\begin{array}{l}50 \% \text { GRD + }+\mathrm{ZnSO}_{4} @ 25 \mathrm{~kg} \\
+ \text { FYM @ 5t/in furrow }\end{array}$ & 17.80 & 30.94 & 1811.75 & 3035.00 & 37.4 & 48.18 \\
\hline $\begin{array}{l}\text { 100\%GRD +Lime@3q/ha } \\
\text { +FYM 5t/ha in furrow }\end{array}$ & 14.00 & 34.37 & 2030.75 & 3307.50 & 38.0 & 48.88 \\
\hline $\begin{array}{l}\text { 100\% GRD + } \mathrm{MgSO}_{4} @ 15 \\
\mathrm{~kg} / \mathrm{ha}+\mathrm{FYM} 5 \mathrm{t} / \mathrm{ha} \text { in } \\
\text { furrow }\end{array}$ & 15.90 & 31.93 & 1917.75 & 3187.50 & 37.6 & 49.18 \\
\hline $\begin{array}{l}\text { 100\% GRD + lime@3q/ha+ } \\
\mathrm{MgSO}_{4} 15 \mathrm{~kg} / \mathrm{ha}+\text { FYM } \\
\text { 5t/ha in furrow }\end{array}$ & 14.23 & 37.27 & 2052.5 & 3292.50 & 38.4 & 49.13 \\
\hline $\mathrm{CV}(\%)$ & 19.39 & 3.34 & 7.1 & 3.60 & 6.46 & 1.99 \\
\hline $\operatorname{CD}(5 \%)$ & 4.19 & 1.54 & 181.9 & 150.6 & 3.54 & 1.36 \\
\hline $\operatorname{CD}(1 \%)$ & 5.79 & 2.12 & 251.4 & 208.1 & 4.48 & 1.87 \\
\hline
\end{tabular}


Table.2 Physico-chemical properties of soil

\begin{tabular}{|l|l|l|}
\hline S.No. & Soil Properties & Values \\
\hline $\mathbf{1}$ & Mechanical composition & \\
\hline & Sand \% & 52 \\
\hline & Silt \% & 26 \\
\hline & Clay \% & 22 \\
\hline & Texture classes & Sandy loam \\
\hline $\mathbf{2}$ & Bulk density & 1.4 \\
\hline $\mathbf{3}$ & Soil $\mathrm{pH}(1: 2: 5)$ & 4.8 \\
\hline $\mathbf{4}$ & $\begin{array}{l}\text { Electrical conductivity } \\
\left.\text { (dSm }^{-1} \text { at } 250 \mathrm{C}\right)\end{array}$ & 0.22 \\
\hline $\mathbf{5}$ & CEC & 14.1 \\
\hline $\mathbf{6}$ & Organic carbon $(\%)$ & 0.61 \\
\hline $\mathbf{7}$ & Available $\mathrm{N}\left(\mathrm{kg} \mathrm{ha}^{1}\right)$ & 205 \\
\hline $\mathbf{8}$ & Available $\mathrm{P}\left(\mathrm{kg} \mathrm{ha}^{1}\right)$ & 12.3 \\
\hline $\mathbf{9}$ & Available $\mathrm{K}\left(\mathrm{kg} \mathrm{ha}^{1}\right)$ & 198 \\
\hline $\mathbf{1 0}$ & Available $\mathrm{S}\left(\mathrm{kg} \mathrm{ha}^{1}\right)$ & 9.7 \\
\hline $\mathbf{1 1}$ & Available $\mathrm{Ca}\left(\mathrm{kg} \mathrm{ha}^{1}\right)$ & 92 \\
\hline $\mathbf{1 2}$ & Available $\mathrm{Mg}\left(\mathrm{kg} \mathrm{ha}^{1}\right)$ & 96 \\
\hline $\mathbf{1 3}$ & Available $\mathrm{Zn}\left(\mathrm{ppm}^{1}\right)$ & 1.2 \\
\hline
\end{tabular}

In conclusions, the application of organics and inorganics nutrients was found better and significantly influenced the growth and yield parameters of groundnut. The application of organics and inorganics nutrients influenced the growth and yield of groundnut significantly and the highest pod yield of groundnut $(20.52 \mathrm{q} / \mathrm{ha})$ were recorded maximum under $\left(\mathrm{T}_{10}\right) \quad 100 \%$ GRD + lime@3q/ha+ $\mathrm{MgSO}_{4} 15 \mathrm{~kg} / \mathrm{ha}+\mathrm{FYM} 5 \mathrm{t} / \mathrm{ha}$ in furrow and the haulm yield (33.07 q/ha) were recorded maximum under $\left(\mathrm{T}_{8}\right) \quad 100 \% \mathrm{GRD}$ +Lime@3q/ ha +FYM 5t/ha in furrow and the control plot experienced low pod and haulm yield of groundnut. The application of either FYM in soil significantly increased the available major nutrients $(\mathrm{N}, \mathrm{P}$ and $\mathrm{K})$ whereas, available micro nutrient $(\mathrm{Zn})$ content in soil were not influenced significantly after harvest of the groundnut crop. The application of organics and inorganics fertilizers in soil significantly improved the oil content in groundnut seeds.

\section{Acknowledgements}

This research was conducted in S.G.CARRS, Jagdalpur,(C.G.) Indira Gandhi Agricultural University, Raipur,(C.G.). I gratefully acknowledge the chairman, Dr. T. Chandrakar who guided me during the experiments and I thank my family members and friends circle also, who havehelped me directly and indirectly.

\section{References}

Badole, S.B., More, S.N., Adsul, P.B., Shaikh, A.K. and Dhamak, A.L. 2004. Residual effect of organic manures and inorganic fertilizers on yield and gross monetary returns of groundnut (Arachishypogaea L.). J. Soils and Crops.14(1): 196-197.

Basu, M., Bhadoria, P. B. S. and Mahapatra, S.C. 2008.Growth, nitrogen fixation, yield and kernel quality of 
peanut in response to lime, organic and inorganic fertilizer levels. Bioresource Technology. 99 (11): 4675-4683

Food and Agricultural Organization, 2011.Report- FAOSTAT Production Year Book.

Gunri, S.K. and Nath, R. 2012. Effect of organic manures, biofertilizers and biopesticides on productivity of summer groundnut (Arachis hypogeae L.). Legume Res. 35 (2):144-148.

Kachot, N.A., Malavia, D.D., Solanki, R.M. and Sagarka, B.K. 2001.Integrated nutrient management in rainy-season groundnut (Arachis hypogaea L.).Indian J. Agronomy. 46 (3): 516-522.

Kachot, N.A., Malavia, D.D., Solanki, R.M. and Sagarka, B.K. 2001.Integrated nutrient management in rainy-season groundnut (Arachishypogaea L.).Indian J. Agronomy. 46 (3): 516-522.

Laxminarayana, K. and Patiram. 2005. Influence of inorganic, biological and organic manures on yield and nutrient uptake of groundnut (Arachishypogaea L.) and soil properties. J. Indian soc.soil sci., 75 (4): 218-221

Panwar, A.S and Munda, G.C. 2007.Response of groundnut (Arachis hypogaea L.) to organic and inorganic sources of nutrient supply under mid-hill altitude conditions.Indian J. Agric. Sci.,77 (12): 814-818.

Pillai, K.G., Devi, S.L. and Setty, T.K.P. 1985. Research achievements of All India Co-ordinated Agronomic
Research Project.Fertilizer News. 30: 26-34.

Singaravel, R., Parasath, V. and Elayaraja, D. 2006.Effect of organics and micronutrients on the growth, yield of groundnut in coastal soil.Internat. J. agric. Sci. 2 (2): 401-402.

Singh, G.P., Singh, P.L. and Panwar, A.S. 2011.Response of groundnut (Arachishypogaea) to biofertilizer, organic and inorganic sources of nutrient in north east India. Legume Res. 34 (3): 196 - 201.

Sonawane, B.B., Nawalkar, P.S. and Patil, V.D. 2010.Effect of micronutrients on growth and yield of groundnut. J. soils and crops, 20 (2): 269-273.

Thomas, A. and Thenua, O.V.S. 2010. Influence of organic and in organic sources of nutrients and their methods of application on growth and yield attributes of groundnut (Arachis hypogeae L.). Indian J. Agric. Res., 44 (3): 216- 220.

Thorave, D.S. and Dhonde, M.B. 2008. Effect of integrated nutrient management on yield and nutrient uptake in summer groundnut. J. Maharashtra Agric. Univ., 33 (2): 284-285.

Zalate, P.Y. and Padmani, D.R. 2009.Effect of organic manure and biofertilizers on yield, harvest index, shelling percentage and quality of kharif groundnut (Arachis hypogeae L.).Internat. J. Agric. Sci., 5 (2): 417-419.

\section{How to cite this article:}

Mukesh Kumar, T. Chandrakar, Dileshwar Prashad Sahu, Karuna Kant Joshi and Poornima Sahu. 2020. Effect of Integrated Nutrient Management on Productivity of Groundnut (Arachis hypogaea L.) and Soil Physical Properties in Bastar Plateau. Int.J.Curr.Microbiol.App.Sci. 9(07): 1054-1059. doi: https://doi.org/10.20546/ijcmas.2020.907.123 